\title{
CORPORATE GOVERNANCE AND BUSINESS PERFORMANCE: EVIDENCE FOR THE ROMANIAN ECONOMY
}

\author{
Monica-Violeta ACHIM ${ }^{1}$, Sorin-Nicolae BORLEA ${ }^{2}$, Codruţa MARE ${ }^{3}$ \\ ${ }^{1,3}$ Babeş-Bolyai University, Faculty of Economics and Business Administration, no. 58-60, \\ Theodor Mihali Street, 400591, Cluj Napoca, Romania \\ ${ }^{2}$ West Vasile Goldis University ,Faculty of Economics, no.15, Mihai Eminescu Street, \\ Arad, 310086, Romania \\ E-mails:1'monica.achim@econ.ubbcluj.ro (corresponding author); \\ ${ }^{2}$ snborlea@yahoo.com; ${ }^{3}$ codruta.mare@econ.ubbcluj.ro
}

Received 26 April 2013; accepted 12 August 2013

\begin{abstract}
Our finding contributes towards the understanding of movements regarding the adoption of corporate governance practice in emerging countries such as Romania and its impact on business performances of a company.

We have developed two econometric models to assess the business performances of the companies listed on Bucharest Stock Exchange, in order to point out the impact of corporate governance on business performances. Our results are inconsistent for the period 2001-2011, but if we consider only 2011, the results document a positive correlation between corporate governance quality and market value of companies, such it is reflected by Tobin's Q. Therefore, our results contribute to the studies relating corporate governance and business performances, as it confirms a positive relationship between the two variables which appears once the Romanian emerging economy has began to adopt the best corporate governance practices.

Firstly, our research has important implications for managers in order to know that the adoption of the best corporate governance practices could contribute to the financial success of the firm. Secondly, the results are useful for any investor who needs to consider the quality of corporate governance as a good predictor for the best rate of return of theirs investments. Moreover, our findings have also implications on policy-makers and regulatory authorities in European developing countries and offer them a barometer of adopting the best corporate governance practices in European space.
\end{abstract}

Keywords: corporate governance, business performance, statistical hypothesis, regression, Romanian market, Comply or Explain Statement.

JEL Classification: M21, M48, M14, C12, C31, C51.

\section{Introduction}

The term corporate governance has emerged in common usage in the 70's, in the United States, in the middle of the Watergate scandal, when it was revealed that U.S. companies were involved in U.S. politics, by making contributions to various political par- 
ties. Later, at the end of the twentieth century, financial scandals like Guinness 1986, Poly Peck International 1989, Maxwell 1991, BCCI 1991, Enron 2001, Allied Irish Bank 2002, WorldCom 2002, Xerox 2002, Merrill Lynch 2002, Parmalat 2003/2004, Andersen 2001/2002, have disrupted the financial world and raised serious issues of trust concerning corporate governance systems. Uncontrolled development of financial innovations, especially derivatives, contributed to the dematerialization of business operations and favoured the creative accounting practices designed to manipulate those who analyze financial statements (Le Roy, Marchesnay 2005).

Sustainable development and, consequently, globalization require new performance standards, that go beyond economic goals. In the new context of sustainable development, new social and environmental standards come to complete the business performances. Nowdays, more than ever the ethical dimension of business is increasingly "the object of debate by business scholars, as well as by business people" (Dinu 2008).

Under the new economic development framework, especially concerning the organization, there is change of business management approaches under the corporate governance systems.

\section{Corporate governance in Romania}

Once the benefits of corporate governance practices have been understood and assimilated by the developed countries, the developing ones have begun to adopt "the best practices" in corporate governance, especially because this need is acutely felt with the changes required by the transition to a market economy (Achim, Borlea 2013).

In 2001, the OECD with the support of USAID, developed a specific program to improve corporate governance in Romania. The OECD/USAID views envisaged by the program were pointing out the following objectives: (i) evaluate corporate governance in Romania; (ii) offer a set of key recommendations for improving corporate governance in Romania and bring it closer to the international standard of the OECD Principles; (iii) identify needed technical assistance in the area of corporate governance; (iv) improve the understanding of present corporate governance practices in Romania, informing the international community about progressive national reform initiatives; and (v) facilitate full Romanian access to the ongoing international dialogue on corporate governance. In conducting the assessment and program formulation, the OECD Principles of Corporate Governance was considered the benchmark (OECD 2001; Popa et al. 2009). The key recommendations constituted a comprehensive agenda for reform, including legislative changes, enforcement, institution building and private behaviour/capacity building.

After an unsuccessful attempt in 2001, in 2008 BSE has adopted a new Corporate Governance Code which is based on the OECD principles of corporate governance. The code came into force from the financial year 2009 and it is voluntarily applied by companies traded on the regulated market operated by BSE. Companies that decide to entirely or partially adopt the Code must annually submit to BSE a statement of compliance or non-compliance with the Code of Corporate Governance ("Comply or Explain Statement") stating that the recommendations have actually been implemented and also the way of implementation (Bucharest Stock Exchange 2008). 


\section{Empirical results regarding the correlation between corporate governance and business performance}

The literature abounds with studies on the impact of effective corporate governance on company performance. Regarding the emerging countries, the consulting firm McKinsey (2001) carried out a study on the topic of awareness of institutional investors in emerging countries (Asia, South-Eastern Europe and Latin American) concerning corporate governance. The study shows that these investors gave at least the same importance to information on corporate governance as to financial information in investment decisions, plus they are willing to pay an added value for companies that apply and respect corporate governance standards. In South-Eastern Europe and Africa this addition can be up to $30 \%$ of market capitalization.

One year later (2002) Standard \& Poor's conducted a study regarding the influence of corporate governance best practices on business performance, by using a sample of 1,600 companies listed on major stock exchanges around the world, representing $75 \%$ of the world stock market. The results of the study are emphasizing a strong correlation between the level of transparency provided through annual reports and market risk as wells as the market value (measured by PBR- Price to Book Ratio).

There are a lot of results that investigate the correlation between corporate governance and business performance, hence in Appendix 1 we reflect our exhaustive research upon.

\section{Research objectives, methodology and data}

\subsection{Research objectives}

Firstly, we are going to test various hypotheses in order to find how corporate governance system influences on the adoption of corporate social responsibility and also on the companies' performance, in Romanian economy. Further, the findings from this research will be used to create a general model for assessing the overall performance of Romanian companies, revealing correlations in various dimensions of performance. Consequently, our research objectives can be structured as follows:

A. Secondary objectives of the research:

a) Developing a corporate governance score, applicable for the Romanian economy.

b) Testing the hypothesis which refers to reflecting the impact of adopting the good corporate governance practices on the corporate social responsibility activities.

c) Testing the hypothesis which refers to reflecting the impact of adopting the good corporate governance practices on the choice to report a "Comply or Explain Statement".

d) Testing the hypothesis which refers to the impact of the adoption of good corporate governance practices on financial performance (overall financial performance, growth rates, liquidity ratios, leverage ratio, level of investment propensity).

$B$. The general objective of the empirical research consists in developing an econometric model for assessing the overall performance of the Romanian companies. 


\subsection{Methodology and data}

In determining the sample we started from the companies traded on the Bucharest Stock Exchange (BSE). At the end of 2012, the BSE traded 106 companies, classified into four categories: I (28), II (52), III (1) and unlisted (26). From the total number of companies we removed the unlisted ones because they are not likely to comply with BSE (so they do not draw and report the "Comply or Explain Statement"). Thus, 81 companies listed on BSE remained in our sample (categories I, II and III respectively). Additionally, we eliminated the financial institutions (banks) and other foreign companies. The final valid sample consists of 76 companies listed on BSE.

\subsubsection{Assesing a corporate governance index}

In evaluating the quality of corporate governance system we will rely on the results of numerous studies which enhance that the main component of corporate governance consists in transparency and disclosure practices (Cromme 2005; Karamanou, Vafeas 2005; Bhat et al. 2006; Aksu, Kosedag 2006; Junarso 2006, Ben Ali 2008; Kuznecovs, Pal 2011; Desoky, Mousa 2012; Ionascu, Olimid 2012). It is also relevant that the international rating agencies (Standards \& Poor's, Credit Lyonnais Securities Asia-CLSA) pay particular attention to the transparency and dissemination practices of information about the company, as an important component in order to develop a corporate governance score.

In this regard we use "Comply or Explain Statement" as a main channel to reflect the transparency and disclosure practices about the corporate governance system of a company. Therefore, we use publicly available "Comply or Explain Statement"1 submitted by all publicly quoted companies on BSE and use answers provided by the companies to create a score that measured the goodness of their corporate governance systems. If the companies do not prepare such a statement, data is taken from the documents published by the BSE listed companies on their own website (directors' annual reports, financial reports or any other useful documents or information publicly available).

Inspiring from Standard and Poor's methodology, we develop a corporate governance score by reclasifying the 51 questions contained in the "Comply or Explain Statement" of BSE into five main area of investigation as follows:

i) Governance structure-G: 10 questions;

ii) Investor relations-I: 10 questions;

iii) Board and management-B: 20 questions;

iv) Financial disclosure-F: 10 questions;

v) Corporate social responsibility-CSR: 1 question (the 51th- the last one).

In order to asses the governance score, we will use all the questions included in the "Comply or Explain Statement" except the last one, regarding CSR activities. This is because performing such kind of activities is not directly a component of corporate governance system but rather a large concept that reflects if companies adopt the longterm sustainability strategies (see Kolk, Pinkse 2009).

\footnotetext{
${ }^{1}$ Available from Internet: http://www.bvb.ro/info/Rapoarte/Diverse/Comply\%20or\%20Explain\%20 Statement.pdf
} 
At each of the 50 questions companies answer with YES/NO and if the answer is NO they have to EXPLAIN. In order to compute a corporate governance score, we will give 1 point for each answer with YES and 0 points for NO. Thus, the minimum governance score obtained by a company is 0 points and the maximum is 50 points.

Since the application of the "Comply or Explain Statement" is relatively new in Romania (starting with the financial year 2009), it takes some time for companies to comply with the new requirements.

Thus, only since 2011, the concerns to provide corporate governance reports are consistent and therefore representative for our study. Therefore we analyzed the "Comply or Explain Statements" for the financial year 2011, statements that companies voluntarily reported to the BSE together with the financial reports on the following year (2012).

\subsubsection{Working hypotheses, variables and data}

In order to achieve the secondary objectives of our research, we firstly intend to test the statistical hypotheses validated in the scientific literature regarding the impact of good corporate practices on the manifestation of corporate social responsibility as well as on various financial indicators (financial performance). The working hypotheses are presented below together with a description of the variables used in each case:

H1: The adoption of good corporate governance practices is reflected in behaviour of companies to report the "Comply or Explain Statement".

a) Numerical variable $\mathrm{CG}=$ Corporate governance score.

b) Dummy variable CE = Reports "Comply or Explain Statement" (YES or NO).

H2: The adoption of good corporate governance practices is reflected in the corporate social responsibility policy conducted by companies.

a) $\mathrm{CG}$, or the individual variables that compound it: $\mathrm{G}=$ Governance structure, $\mathrm{I}=$ The investor relations, $\mathrm{B}=$ Board and management, $\mathrm{F}=$ Financial disclosure.

b) Dummy variable CSR = Corporate Social Responsibility (YES, if company performs CSR activities and NO, if company does not perform CSR activities).

H3: The adoption of good corporate governance practices has an impact on the overall financial performance of the company.

a) $\mathrm{CG}$.

b) Numerical variables $\mathrm{CAP}=$ market capitalization, $\mathrm{PBR}=$ Price to book ratio (Market value/Book value), TQ = Tobin's ((stock market capitalization + debt)/ assets), ROA = Return on assets (net income/assets), ROE = Return on equity (Net profit/equity).

H4: The adoption of good corporate governance practices has an impact on the economic growth rates.

a) CG.

b) Numerical variable GROW = Growth rate of turnover (turnover variation/basic turnover). 
H5: The adoption of good corporate governance practices has an impact on the degree of company's liquidity.

a) $\mathrm{CG}$.

b) Numerical variable FLEX = Financial flexibility (working capital/assets) and $\mathrm{CW}=$ Cash flow to assets (Cash flow/Assets).

H6: The adoption of good corporate governance practices is reflected in high levels of financial leverage.

a) CG.

b) Numerical variable LEV = Financial leverage (total debt/equity).

H7: The adoption of good corporate governance practices is reflected in a lower level of investment propensity.

a) CG.

b) Numerical variable EFA = Equity to fixed assets ratio (Shareholder equity/fixed assets).

The hypotheses made were tested through two types of methods: the correlation coefficients and the ANOVA analysis of variances (Buiga 2011).

In order to achieve the general objective of our research we considered as a proxy for the endogenous variables the performance of the company on the market, namely: Market capitalization-CAP, Price to book ratio (ratio between market value and book value) $-P B R$ and Tobin's $Q-T Q$.

We selected two groups of indicators as exogenous variables:

a) internal (economic) performance achieved by the company, represented in the scientific literature by: Return on assets (Net profit/Total assets) - ROA; Return on equity (Net profit/ Shareholder equity) - ROE; Leverage ratio (Debts/ Shareholder equity) - LEV; Equity-to-fixed-assets ratio (Shareholder equity/fixed assets) - EFA; Flexibility ratio (Net working capital/Total assets) - FLEX; Growth ratio (Turnover deviaton/Basis Turnover) - GROW; Cash flow return on assets (Cash flow/total assets) $-\mathrm{CW}$;

b) the corporate governance index $(C G)$ and the corporate social responsibility activities adopted by the company (CSR).

The average values or the standards deviations were computed for each of the variables for the period under analysis and cross-section analysis was applied to construct the models. The multiple regression procedures were applied to estimate models such as:

$$
Y=\beta_{0}+\beta_{i} X_{i}+\varepsilon_{i}
$$

All the necessary validation procedures were run to insure the statistical significance of the models resulted (Dragos 2008).

The financial reports of the companies in the sample were used to evaluate financial performance. The time span is 2001-2011. 


\section{Research results}

\subsection{Hypotheses testing}

The analysis revealed in the following results in what regards the tested hypotheses.

Hypothesis 1 is accepted on our sample at a significance level of $1 \%$. The correlation coefficient resulted from the analysis has a value of 0.683 , with a critical value Sig. $=$ 0.000 . The same Sig. value was returned by the Fisher test in the ANOVA analysis. Moreover the group descriptive statistics clearly show that the average governance score for those who report the "Comply or Explain Statement" is triple than of those who do not (Appendix 2). We can thus conclude that a strong corporate governance system (reflected in a high score of corporate governance) is correlated with the management's decision to report the "Comply or Explain Statement".

Results are in accordance to those found in the scientific literature (McKinsey 2001; Standard \& Poor's 2002; Aksu, Kosedag 2006; Stilgbauer 2010; Fulop 2011).

Results are more or less the same in what regards hypothesis 2. The relationship is also statistically significant at $99 \%$ level - it is positive and medium in intensity (correlation coefficient $=0.651$, Sig. $=0.002$ ).

Taking into consideration the fact that corporate governance score is computed based on four indicators, we ran the above analysis individually, for each component and level of social responsibility, in order to rank the four areas of governance based on their correlation with the level of corporate social responsibility practices. The same value of Sig. in all the four cases $(0.000)$ provides validation of working hypotheses to a confidence level of $99 \%$. Regarding the actual relationship between each component of CG and CSR, the connection is direct and of medium intensity in all the cases. However, the highest coefficient is for aspects related to the Board and management (B) (0.642), while aspects related to the Investors relations (I) are the ones with the lowest influence (0.522). The coefficients of Governance structure (G) and Financial transparency (F) are 0.607 and 0.593 respectively. Social responsibility practices positively influence corporate governance and conversely, a high quality system of corporate governance is reflected in the adoption of a high degree of corporate social responsibility, with the strongest influence given by the Board and management component (B).

Results are consisted with McLaren (2004), Monks et al. (2004), Aguilera et al. (2006), Sjöström (2008), Kolk and Pinkse (2009).

Based on the results of the correlation analysis, we can conclude the following:

a) Between corporate governance (CG) and stock performance indicators (CAP, PBR and TQ) is a significant direct relationship of low intensity ( $95 \%$ confidence level). The most "powerfull" connection would be the one between CG and PBR score (0.27) followed by CG $v s$. CAP and CG vs. TQ $(0.239$, each).

b) When assessing GC vs. economic performance, the strongest relationship is between CG and ROA. It is direct and of medium intensity $(0.357>0.3)$ and it is accepted at a significance level of $1 \%$. Regarding the correlation with ROE, it is not statistically significant for the present sample. 
Hypothesis 3 is accepted on the level of performance represented by ROA (medium intensity), PBR (low intensity) and CAP and TQ (very weak intensity). When the company's performance is represented by ROE the assumption is invalidated. A positive relationship between good corporate practices and financial performances has been established by numerous expert studies: McKinsey (2001), Standard \& Poor's (2002), Klapper and Love (2004), Doidge et al. (2007), Al-Hussain and Johnson 2009, Stilgbauer 2010, Kusnecovs 2011, Feleagă et al. (2011), Arcot and Bruno (2011), Agrawal and Knoeber (2012).

The weakest significance level (10\%) appears for the relationship between growth rate and governance score (correlation coefficient $=0.209$, Sig. $=0.071$ ) (The turnover is also in a weak direct relationship with the governance (correlation coefficient $=0.263$ ) but the result is accepted with a probability of $95 \%$. In other words, the adoption of good corporate practice generates an increase in the company's activity (expressed with a growth of the turnover and its growth rate). In conclusion, hypothesis 4 is accepted at a low intensity (below 0.3). Results are in line with those obtained by Klapper and Love (2004), Doidge et al. 2007, Agrawal and Knoeber (2012).

Hypothesis 5 is rejected in our analysis. Results differ by the scientific literature, being devoted to the positive impact of good corporate governance practices on the degree of liquidity of the company (Eng, Mak 2003; Li, Qi 2008; Stiglbauer 2010). The adoption of good corporate governance practices is not reflected in the liquidity of the company. The analysis has returned very low levels of the correlation coefficients, both for financial flexibility and cash flow through assets (0.027 and 0.029).

There is an insignificant very low and indirect connection between corporate governance and financial leverage $(-0.156)$. Thus, the correlation shows that the adoption of good corporate governance practices is reflected in a low level of indebtedness, evidenced by the financial leverage indicator (debt/equity). In conclusion, hypothesis 6 is also rejected on our sample. Thus, Romanian companies have not been identified with such a correlation, debated in the literature (Jensen 1986; Driffield et al. 2005; Cremers, Vinay 2005; Kuznecovs, Pal 2011). The next hypothesis (H7) is also rejected, the correlation between corporate governance score and propensity to investment being statistically not significant.

We can therefore say that the adoption of good corporate governance practices is reflected in a higher aversion risk, thus a balanced investment policy. Results converge with those reached by a number of authors, such as: Jensen and Meckling (1976), Gompers, Ishii and Metrick (2003), Arcot and Bruno (2011).

\subsection{Constructing a model for global business performance}

Regarding the overall objective of the research to develop an econometric model to assess the overall performance, the analysis was made in two steps.

For the first, given the large number of variables used and the long analyzed period (2001-2011), running the tests of correlation using variable averages, leads to inconsistent results. Therefore, the next step was to test the correlations using the standard 
deviations of the variables (as a measure of volatility). Applying the procedures upon the level of volatility, although many of the variables selected were rejected from the model, some significant connections still remained.

Thus, of the three endogenous variables (CAP, PBR and TQ) the correlations persist at a significant level only for the PBR (Appendix 3). Next we retain as the only endogenous variable the PBR. In what the remaining exogenous variables are concerned, after running the tests only four variables remain significant: ROE, LEV, GROW and CAP. The adjusted $\mathrm{R}^{2}$ of 0.355 shows that the exogenous variables determine the endogenous variables on a rate of $35.5 \%$. The model is statistically significant $(\mathrm{Sig}=0.000)$. The standardized form of the econometric model is as follows:

$$
\mathrm{PBR}=-0.425 \mathrm{ROE}+0.366 \mathrm{LEV}-0.893 \mathrm{GROW}+1.125 \mathrm{CAP} .
$$

Unfortunately, for the analyzed period (2001-2011), we couldn't reach a statistically consistent econometric model of the overall performance of the company to incorporate a large number of variables validated by the scientific literature as being significant for determining the overall performance (stock) of the company. To the variables rejected we can also add the ones related to the adoption of good practices (corporate governance) and corporate social responsibility.

The unconvincing conclusions that we reached, in relation to the set expectations, lead us to the evaluation of the same correlations, but only for 2011 (most recent year in which it is assumed that the practices of corporate governance and CSR are most intense, with the need to converge to EU requirements).

The results of the research for 2011 show an adjusted $R^{2} 0 f 0.433$. The exogenous variables are best correlated with the endogenous variable which reflects the stock performance, TQ. Among the exogenous variables selected, there are a significant number of variables that remain such as: ROA, ROE, LEV, EFA, and CW.

The econometric model that assesses the company's performance represented by the Tobin's Q (TQ) is:

$$
\begin{aligned}
& \mathrm{TQ}=-1.673 \mathrm{ROA}+0.475 \mathrm{ROE}+0.038 \mathrm{LEV}-0.203 \mathrm{EFA}+0.4999 \mathrm{FLEX}+ \\
& 0.009 \mathrm{GROW}+1.242 \mathrm{CW}+0.003 \underline{\mathrm{CG}}+0.182 \underline{\mathrm{CSR}}+0.556 .
\end{aligned}
$$

The econometric model for the global performance reflects the highest influences of ROA and CW. However the type of influence is different. CSR and CG have a weak but positive influence on market value reflected by Tobin's Q, even these variables are not statistically significant.

The results on the structure of the econometric model meant to assess the overall performance of the company appear in 2011, as being on the same level with the results devoted by the scientific literature. The long analysis period (2001-2011) with fluctuating results in the emerging economy in a country like Romania, which is interrupted by the global financial crisis, causes the generation of less consistent results that can be embedded in an econometric solid model. In 2011 only, results appear to be more balanced 
and more relevant, and we can build a consistent global evaluation model including also the corporate governance influence. The obtained results document a positive impact of corporate governance on business performances, measured by Tobin's Q. Therefore, the obtained results are in accordance to other previous studies in literature, reflecting a positive correlation between the two variables (Black et al. 2005, 2006; Ficici, Aybar 2012; Fallatah, Dickins 2012; Wang 2014).

\section{Conclusions}

Corporate governance is increasingly recognized as a key element in attracting investments and increasing the business performance and competitiveness of a company.

A first objective of our research consist in developing a methodology for assessing the quality of corporate governance, including an index of corporate governance, adapted to the national development framework of the Romanian economy and also to the Corporate Governance Code of the Bucharest Stock Exchange.

Some important statistical hypotheses related to the impact of good corporate practices on companies' performance, which have already been confirmed by the literature, have been tested on the Romanian economy. The results have materialized in the acceptance of four out of the seven hypotheses reflecting that Romanian companies increasingly more the need to adopt the best practices of corporate governance and "theirs trajectory is a positive and a progressive one" (Bota-Avram 2012).

Also, we have developed two econometric models to assess the global performances of the company. For the 2001-2011 period, results based on cross-section analysis are inconsistent and cannot be materialized in an econometric model that incorporates a significant number of high factors confirmed by the literature as statistically significant in determining the company's performance. Among the variables rejected by the model, there are the variables related to the adoption of good practices in corporate governance. Results are more consistent when assessing only 2011, when we identify a positive correlation between corporate governance and business performances reflected by Tobin's $\mathrm{Q}$, even if it is not yet statistically significant.

This research contributes towards the understanding of movements regarding the adoption of corporate governance practice in emerging countries such as Romania and its impact on business performances of a company.

Our research further contributes to the studies relating corporate governance and business performances, as it confirms a positive relationship between the two variables which runs once the Romanian emerging economy began to realize the need to adopt best practices in corporate activity.

Our results have important implications mainly for managers in order to know that the adoption of the best practices in governance could contribute to the financial success of the firm. Also, the results suggest that investors must consider the quality of corporate governance as a good predictor of the best rate of return of theirs investments and they "need to be extra cautious when investing in firms with less stringent corporate gover- 
nance mechanisms" (Ficici, Aybar 2012). Moreover, our results have also implications on policy-makers and regulatory authorities in European developing countries and give them a barometer of adopting the best practices in governance in European space.

The limitations of the paper could consist in the short period in which we can talk about corporate governance in Romania, as European emerging country. Since the application of the Comply or Explain Statement started only with the financial year 2009, we use 2011 year when the concerns to provide corporate governance reports are as consistent is possible. As the principles of corporate governance will be better known and adopted by developing economy (including also Romania), future studies will run on a longer period of applying best practices in corporate governance in Romanian emerging market.

Another limit of the present research could be the fact that by using Comply or Explain Statement, some main characteristics of corporate governance are not very well encapsulated (such as age diversity, gender or nationality of board members or block and institutional ownership issues) and therefore the quality of corporate governance could be somehow distorted. Future studies will be developed by completing the score of corporate governance with many other variables which are not reflected in Comply or Explain Statement, in order to get more robustness results.

\section{References}

Achim, M. V.; Borlea, N. S. 2013. Corporate governance and business performances. Modern approaches in the new economy. Germany: Lap Lambert Academic Publishing.

Aguilera, R. V.; Filatotchev, I.; Gospel, H.; Jackson, G. 2006. An organizational approach to comparative corporate governance: costs, contingencies, and complementarities [online], [cited April 2013]. Available from Internet: http://www.kcl.ac.uk/sspp/departments/management/ research/papers/theme/hrm/ob/governance.pdf

Agrawal, A.; Knoeber, Ch. R. 2012. Corporate governance and firm performance, in R. T. Christopher, W. F. Shughart II (Eds.). Oxford handbook in managerial economics, Chapter 26. New York, NY: Oxford University Press.

Al-Hussain, A. H.; Johnson, R. L. 2009. Relationship between corporate governance efficiency and Saudi banks' performance, The Business Review 14(1): 111-117.

Aksu, M.; Kosedag, A. 2006. Transparency and disclosure scores and their determinants in the Istanbul stock exchange, Corporate Governance 14(4): 277-296.

http://dx.doi.org/10.1111/j.1467-8683.2006.00507.x

Arcot, S; Bruno, V. 2011. Silence is not golden: corporate governance standards, transparency, and performance, Working paper [online], [cited April 2013]. Available from Internet: http:// www.parisschoolofeconomics.eu/IMG/pdf/sarcot_1105.pdf

Bauer, R.; Gunster, N.; Roger Otten, R. 2003. Empirical evidence on corporate governance in europe, the effect on stock returns, firm value and performance, Journal of Asset Management 5: 91-104. http://dx.doi.org/10.1057/palgrave.jam.2240131

Ben Ali, C. 2008. Disclosure quality and corporate governance: evidence from the French Stock Market, Post-Print halshs-00522350, HAL [online], [cited April 2013]. Available from Internet: https://halshs.archives-ouvertes.fr/file/index/docid/522350/filename/p153.pdf 
Bistrova, J.; Lace, N. 2012. Quality of corporate governance system and quality of reported earnings: evidence from CEE companies, Economics and Management 17(1): 55-61.

http://dx.doi.org/10.5755/j01.em.17.1.2251

Bhat, G.; Hope, O. K.; Kang, T. 2006. Does corporate governance transparency affect the accuracy of analyst forecasts?, Accounting \& Finance 46: 715-732.

http://dx.doi.org/10.1111/j.1467-629X.2006.00191.x

Black, B. S.; Kim, W.; Jang, H.; Park, K. S. 2005. How corporate governance affects firm value: evidence on channels from Korea [online], [cited February 2015]. Available from Internet: http:// papers.ssrn.com/sol3/papers.cfm?abstract_id=1365945

Black, B. S.; Love, I.; Rachinasky, A. 2006. Corporate governance indices and firms' market values: time series evidence from Russia, Emerging Markets Review 7(4): 361-379.

http://dx.doi.org/10.1016/j.ememar.2006.09.004

Boţa-Avram, C. 2012. Determining a scoring of financial audit practices used by most significant companies listed on Bucharest Stock Exchange, in the context of corporate governance, Revista de Audit Financiar 10(94): 30-40.

Bucharest Stock Exchange. 2008. Corporate Governance Code [online], [cited April 2013]. Available from Internet: http://www.ecgi.org/codes/documents/bucharest_se_code_jan2009_en.pdf.

Brown, L. D.; Caylor, M. L. 2006. Corporate governance and firm valuation, Journal of Accounting and Public Policy 25: 409-434. http://dx.doi.org/10.1016/j.jaccpubpol.2006.05.005

Buiga, A. 2011. Inferential statistics. Applications in SPSS. Cluj-Napoca: Todesco Publishing House.

Cremers, K. J. M.; Vinay, B. N. 2005. Governance mechanisms and equity prices, The Journal of Finance 60(6): 2859-2894. http://dx.doi.org/10.1111/j.1540-6261.2005.00819.x

Cromme, G. 2005. Corporate governance in Germany and the German Corporate Governance Code, Corporate Governance: an International Review 13(3): 362-367.

Desoky, A. M.; Mousa, G. A. 2012. Corporate governance practices: transparency and disclosure - evidence from the Egyptian exchange, Journal of Accounting, Finance and Economics 2(1): 49-72.

Dinu, V. 2008. The ethical dimensions of business, Amfiteatru Economic 10(23): 7-10.

Doidge, C.; Karolyi, A.; Stulz, R. M. 2007. Why do countries matter so much for corporate governance?, Journal of Financial Economics 86: 1-39. http://dx.doi.org/10.1016/j.jfineco.2006.09.002

Dragos, C. 2008. Basic of econometrics and econometric modelling. Cluj-Napoca: Mediamira Publishing.

Driffield, N.; Vidya, M.; Sarmistha, P. 2005. How ownership structure affects capital structure and firm performance? Recent evidence from East Asia, Working Paper [online], [cited April 2013]. Available from Internet: http://129.3.20.41/eps/fin/papers/0505/0505012.pdf.

Eng, L. L.; Mak, Y. T. 2003. Corporate governance and voluntary disclosure, Journal of Accounting and Public Policy 22: 325-345. http://dx.doi.org/10.1016/S0278-4254(03)00037-1

Fallatah, Y.; Dickins, D. 2012. Corporate governance and firm performance and value in Saudi Arabia, African Journal of Business Management 6(36): 10025-10034.

http://dx.doi.org/10.5897/AJBM12.008

Feleagă, N.; Feleagă, L.; Dragomir, V. D.; Bigioi, A. D. 2011. Guvernanţa corporativă în economiile emergente: cazul României, Economie teoretică şi aplicată 9(562): 3-15.

Ficici, A.; Aybar C. B. 2012. Corporate governance and firm value in emerging markets an empirical analysis of ADR issuing emerging markets firms, Emerging Markets Journal.

http://dx.doi.org/10.5195/emaj.2012.18 
Fulop, M. 2011. Audit in corporate governance: Doctoral thesis. Babes-Bolyai University, ClujNapoca, Romania.

Gawer, J. 2012. Corporate governance scores and long term performance, in 29th Spring International Conference of the French Finance Association, 15-16 May 2012, Strasbourg, France.

Gompers, P. A.; Ishii, J.; Metrick, A. 2003. Corporate governance and equity prices, Quarterly Journal of Economics 118(1): 107-155. http://dx.doi.org/10.1162/00335530360535162

Hugill, A.; Siegel, J. 2012. Which does more to determine the quality of corporate governance in emerging economies, firms or countries?, Working Paper [online], [cited April 2013]. Available from Internet: http://www.hbs.edu/faculty/Publication\%20Files/13-055_5b0cfedd-cefe4592-bd7e-178b566fc523.pdf

Ionascu, M.; Olimid, L. 2012. The impact of corporate governance practices on financial analysts' forecasts: the case of Romania, Revista de Audit Financiar 10(88): 31-36.

Jensen, M. C. 1986. Agency cost of free cash flow, corporate finance and takeovers, American Economic Review Papers and Proceedings 76: 323-329.

Jensen, M. C.; Meckling, W. H. 1976. Theory of the firm: managerial behaviour, agency costs and ownership structure, Journal of Financial Economics 3(4): 305-360.

http://dx.doi.org/10.1016/0304-405X(76)90026-X

Junarso, T. 2006. Comprehensive approach to corporate governance. iUniverse USA.

Karamanou, I.; Vafeas, N. 2005. The association between boards and audit committees with management earnings forecasts: an empirical analysis, Journal of Accounting Research 43(3): 453-486. http://dx.doi.org/10.1111/j.1475-679X.2005.00177.x

Klapper, L. F.; Love, I. 2004. Corporate governance, investor protection, performance in emerging market, Journal of Corporate Finance 10(5): 703-728.

http://dx.doi.org/10.1016/S0929-1199(03)00046-4

Kolk, A.; Pinkse, J. 2009. The integration of corporate governance in corporate social responsibility disclosure [online], [cited April 2013]. Available from Internet: http://ssrn.com/abstract $=1350939$

Kowalewski, O. 2012. Does corporate governance determine corporate performance and dividends during financial crisis: evidence from Poland, Working Papers. Financial Institutions Center, Wharton School, University of Pennsylvania. 12, 14.

Kuznecovs, M.; Pal, S. 2011. Does corporate governance reform necessarily boost firm performance? Recent evidence from Russia, Working Paper No. 11-06. Centre for Economic Development \& Institutions, Brunel University, West London, UK.

Larcker, D.; S. Richardson; Tuna, I. 2007. Corporate governance, accounting outcomes, and organizational performance, Accounting Review 82(July): 963-1008.

http://dx.doi.org/10.2308/accr.2007.82.4.963

Le Roy, F; Marchesnay, M. 2005. La responsabilité sociale de l'entreprise. Paris: Éditions EMS. Li, H.; Qi, A. 2008. Impact of corporate governance on voluntary disclosure in Chiness listed companies, Corporate Ownership \& Control 5(2): 360-366.

Mironiuc, M. 2009. Financial analysis versus extra-financial analysis in the context of sustainable development, in Supplement of Theoretical and Applied Economics Revue, 29-31 May 2009, Bucharest, 151-167.

McKinsey Emerging Market Investor Opinion Survey. 2001. Corporate reform agenda in the developing world [online], [cited April 2013]. Available from Internet: www.mckinseyquarterly. com.

McLaren, D. 2004. Global stakeholders: corporate accountability and investor engagement, Corporate Governance: an International Review 12(2): 191-201.

http://dx.doi.org/10.1111/j.1467-8683.2004.00360.x 
Monda, B.; Giorgino, M. 2013. Corporate governance and shareholder value in listed firms: an empirical analysis in five countries (France, Italy, Japan, UK, USA) [online], [cited April 2013]. Available from Internet: http://mpra.ub.uni-muenchen.de/45429/

Monks, R.; Miller, A.; Cook, J. 2004. Shareholder activism on environmental issues: a study of proposals at large US corporations (2000-2003), Natural Resources Forum 28: 317-330.

http://dx.doi.org/10.1111/j.1477-8947.2004.00104.x

OECD. 2001. Corporate governance in Romania [online], [cited April 2013]. Available from Internet: http://www.oecd.org/corporate/ca/corporategovernanceprinciples/2390703.pdf

Popa, A.; Blidişel, V.; Bogdan, V. 2009. Transparency and disclosure between theory and practice. A case study of Romania, in Proceedings of FIKUSZ '09 Symposium for Young Researchers, 2009, 173-183 [online], [cited April 2013]. Available from Internet: http://econpapers.repec.org/ bookchap/pkksfyr09/173-183.htm

Renders, A.; Gaeremynck, A.; Sercu, P. 2010. Corporate-governance ratings and company performance: a cross-European study, Corporate Governance: an International Review 18(2): 87-106. http://dx.doi.org/10.1111/j.1467-8683.2010.00791.x

Sjöström, E. 2008. Shareholder activism for corporate social responsibility: what do we know?, Sustainable Development 16: 141-154. http://dx.doi.org/10.1002/sd.361

Standard \& Poor's Corporate Governance Scores. 2002. Criteria, methodology and definitions, July 2002 [online], [cited April 2013]. Available from Internet: http://www.kantakji.com/media/3339/w116.pdf.

Stiglbauer, M. 2010.Transparency \& disclosure on corporate governance as a key factor of companies' success: a simultaneous equations analysis for Germany, Problems and Perspectives in Management 8(1): 161-173.

Wang, M. C. 2014. The value relevance of Tobin's Q and corporate governance for the Taiwanese tourism industry, Journal of Business Ethics. http://dx.doi.org/10.1007/s10551-014-2339-9 


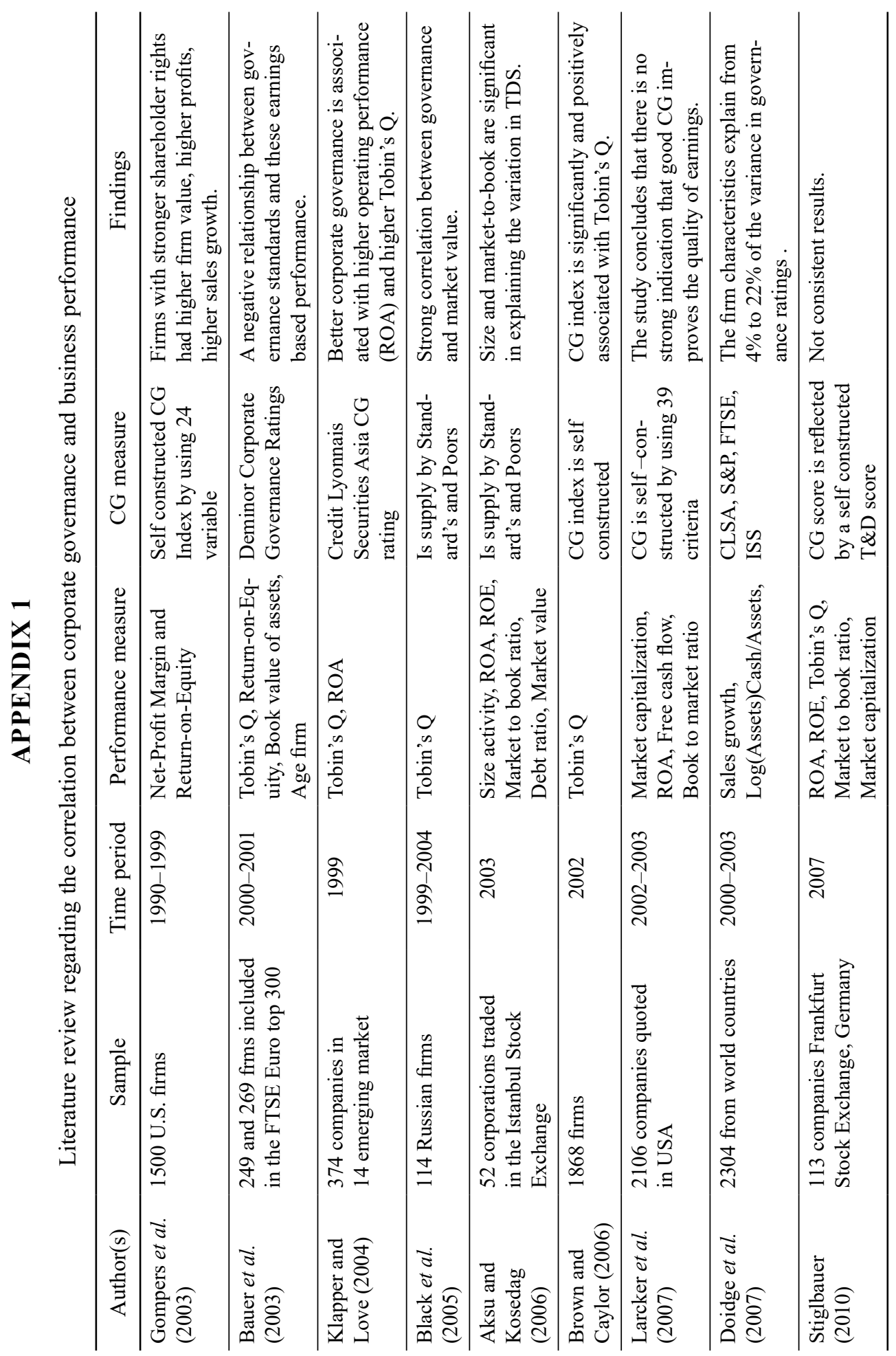




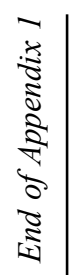

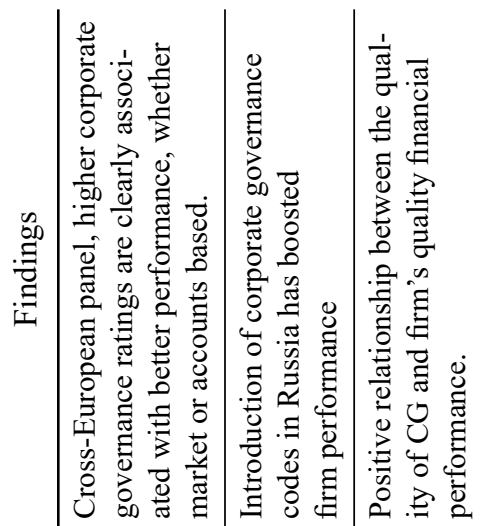

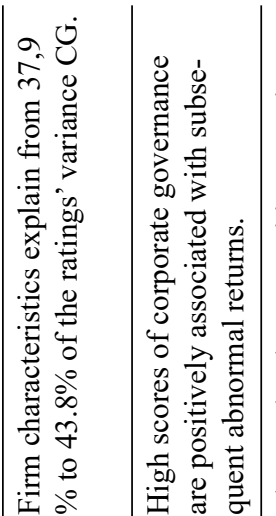

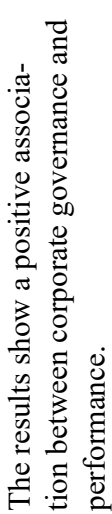

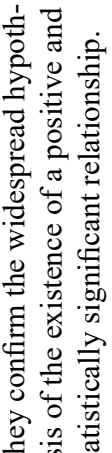

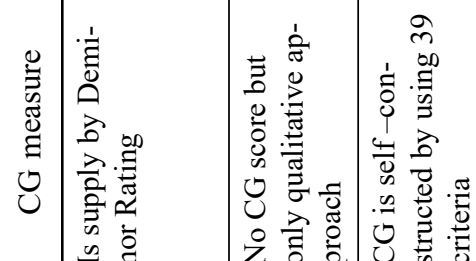

E

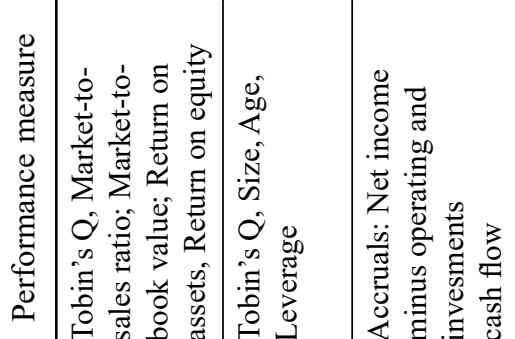

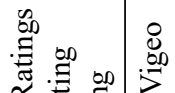

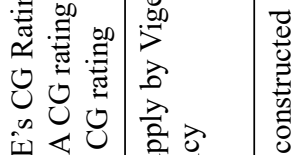

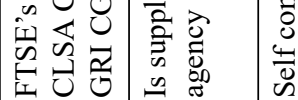

오

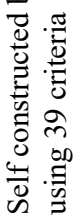

晃 ఫे

声

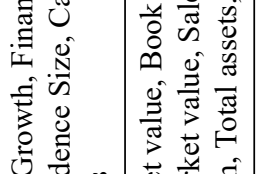

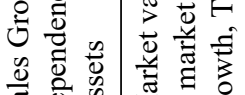

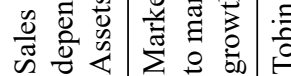

올

ชิ

घ

各

응

$\stackrel{0}{\stackrel{0}{0}}$

웅

ᄋे 융

ஓ্ণ

๙

옹

$\stackrel{0}{\exists}$

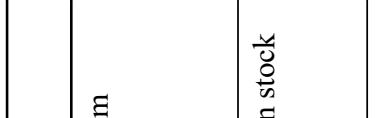

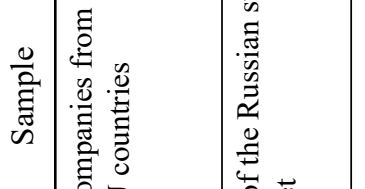

苋

$\infty$

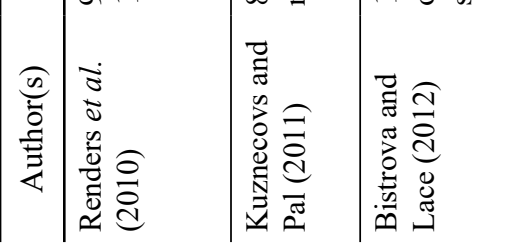

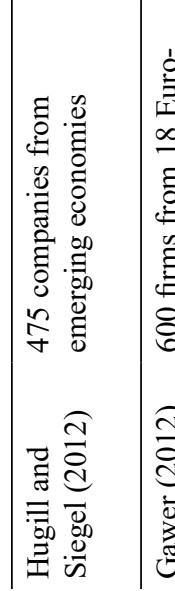

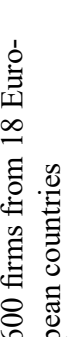

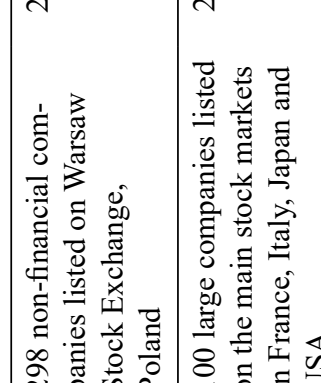




\section{APPENDIX 2}

Group descriptive statistics - corporate governance score (CG) vs. reporting "Comply or Explain Statement" (A) and CSR activities (B)

\begin{tabular}{ccccccccc}
\hline & \multicolumn{2}{c}{$\mathrm{N}$} & \multicolumn{2}{c}{ Mean of CG } & \multicolumn{2}{c}{ Minimum of CG } & \multicolumn{2}{c}{ Maximum of CG } \\
\cline { 2 - 9 } & $(\mathrm{A})$ & $(\mathrm{B})$ & $(\mathrm{A})$ & $(\mathrm{B})$ & $(\mathrm{A})$ & $(\mathrm{B})$ & $(\mathrm{A})$ & $(\mathrm{B})$ \\
\hline No & 22 & 19 & 11.68 & 10.26 & 0 & 0 & 49 & 38 \\
\hline Yes & 54 & 57 & 36.44 & 35.61 & 8 & 5 & 49 & 49 \\
\hline Total & 76 & 76 & 29.28 & 29.28 & 0 & 0 & 49 & 49 \\
\hline
\end{tabular}

Source: own calculation using SPSS 17.0.

\section{APPENDIX 3}

Econometric model PBV vs. CAP, ROE, LEV, GROW

\begin{tabular}{|c|c|c|c|c|c|}
\hline \multicolumn{6}{|c|}{ Coefficients } \\
\hline \multirow[t]{2}{*}{ Model } & \multicolumn{2}{|c|}{ Unstandardized coef. } & \multirow{2}{*}{$\frac{\text { Standardized coef. }}{\text { Beta }}$} & \multirow[t]{2}{*}{$\mathrm{t}$} & \multirow[t]{2}{*}{ Sig. } \\
\hline & $\mathrm{B}$ & $\begin{array}{l}\text { Std. } \\
\text { Error }\end{array}$ & & & \\
\hline (Constant) & 1.146 & 0.203 & - & 5.655 & 0.000 \\
\hline ROE & -0.767 & 0.289 & -0.425 & -2.651 & 0.010 \\
\hline LEV & 0.031 & 0.014 & 0.366 & 2.278 & 0.026 \\
\hline GROW & -2.248 & 0.439 & -0.893 & -5.118 & 0.000 \\
\hline CAP & 0.000 & 0.000 & 1.125 & 6.441 & 0.000 \\
\hline
\end{tabular}

Source: own calculation using SPSS 17.0.

Monica-Violeta ACHIM is currently Associate Professor PhD at Finance Department, Faculty of Economics and Business Administration, Babeş-Bolyai University, Cluj-Napoca, Romania. Her research interests are focused on business and finance with particular emphases on financial analysis and diagnosis of companies. She is also Financial Auditor and Accounting Expert, member of the Chamber of Financial Auditors and Chamber of Accounting Experts in Romania.

Sorin-Nicolae BORLEA is currently Professor PhD at Finance and Accounting Department, Faculty of Economics, West Vasile Goldis University, Arad, Romania. He teaches the courses in Financial Analysis, Corporate governance, Financial Audit and Accounting. He is also Financial Auditor and Accounting Expert, member of the Chamber of Financial Auditors and Chamber of Accounting Experts in Romania.

Codruța MARE is currently Associate Professor PhD at the Department of Statistics - Forecasting - Mathematics, Faculty of Economics and Business Administration, Babeş-Bolyai University, Cluj-Napoca, Romania. She is the tenure teacher for the courses in Economic Forecasting, Spatial Econometrics, Demography and Descriptive Statistics and helds seminars in Inferential Statistics and Basic Econometrics. She got her PhD in Italy in 2010. 